\title{
Should We Really Compare Indwelling Pleural Catheters to Any Pleurodesis?
}

\author{
Marios E. Froudarakis \\ Department of Pneumonology, Medical School of Alexandroupolis, Democritus University of Thrace, \\ Alexandroupolis, Greece
}

Pleural effusion is a common manifestation of malignancies, which either reveals the disease or occurs during the course of the disease. Overall, 150,000 new cases of malignant pleural effusions (MPE) are reported every year in the USA. Any neoplasm may lead to this manifestation: in primary tumors of the pleura (mesothelioma), it occurs in up to $95 \%$ of the cases, whereas in metastatic neoplasms in males lung carcinomas account for $40 \%$ and in females breast carcinomas account for $30 \%[1,2]$. Although the survival of patients with MPE is globally reported to be poor, we have to differentiate between patients with MPE as an initial manifestation of the disease, who are naïve to any treatment, and patients with MPE occurring during disease progression, who are relapsing and/or resisting to treatment [3].

Pleurodesis is a process involving multiple inflammatory cells recruited by cytokines, which leads to a coagulation-fibrinolysis imbalance and finally a development of adhesions between visceral and parietal pleurae in order to obliterate the pleural space to palliate effusion and symptoms [4]. Relief of dyspnea may be obtained regardless of radiographic findings. For pleurodesis, many compounds have been tested. The cheapest compound providing long-lasting pleurodesis is sterile, asbestos-free, calibrated Luzenac talc [5]. Talc insufflation, after evacu- ation of the fluid and adhesiolysis during thoracoscopy, showed excellent immediate (>90\%) and 1-year ( $85 \%)$ results [6], with few side effects, producing better quality and quantity of pleural symphysis compared to talc slurry [7]. Talc seems to have another interesting local antitumor effect, the induction of apoptosis of cancer cells [4, 8]. Iodopovidone is an interesting alternative to talc for pleurodesis as it is cheap, safe and showed high efficacy rates (90\%) [9]. Many chemotherapeutic agents, such as bleomycin, cisplatin and taxanes, which have lower efficacy but at the same time highest costs, have been tested [10]. New molecules such as cytokines (transforming growth factor- $\beta$ ), which are involved in the coagulation cascade [11], are expensive, and data in humans are still lacking. To date, thoracoscopy with Luzenac talc poudrage remains the most effective low-cost method of pleurodesis in patients with MPE, a good performance status and long life expectancy [12-14].

Studies reporting data from patients with recurrent non-MPE are mainly retrospective or include only a small number of patients with many different causes of their disease (inhomogeneous population) [15-17]. Frequently, benign diseases necessitating an intervention in case of refractory pleural effusion are congestive heart failure, renal failure and hepatic cirrhosis $[15,16]$. Patients with

\section{KARGER}

E-Mail karger@karger.com

www.karger.com/res
C 2014 S. Karger AG, Basel

0025-7931/14/0881-0018\$39.50/0
Marios E. Froudarakis, MD, $\mathrm{PhD}$

Department of Pneumonology

University Hospital of Alexandroupolis

GR-68100 Alexandroupolis (Greece)

E-Mail mfroud@med.duth.gr 
these diseases consult physicians repeatedly over a short period of time in order to palliate dyspnea, the leading symptom, which is, however, not only caused by the presence of effusion. They do not respond to diuretic therapy or develop diuretic-related complications that prevent the use of high doses of these drugs [16]. In these patients, many interventions, such as repeated thoracocentesis, pleurodesis, pleuroperitoneal, transjugular intrahepatic portosystemic shunts or repair of the defects of the diaphragm, may be considered depending on the underlying disease and the patients' health status. In these cases, pleurodesis performed with talc (poudrage or slurry) or autologous blood proved neither efficient nor longlasting. Interventions such as pleuroperitoneal shunts, transjugular intrahepatic portosystemic shunts or diaphragmatic defect repair are invasive, costly procedures which need to be dealt with by experienced teams $[16,18]$. In practice, many of these patients are subjected to frequent and repeated therapeutic thoracocenteses in order to drain as much fluid as possible from their pleura for symptom relief.

In the last decade, indwelling pleural catheters (IPCs) have been developed and studied mainly in MPE patients (see Bhatnagar and Maskell [19] in this issue of Respiration). The primary goal of treatment is the relief of dyspnea rather than pleurodesis, yet 'spontaneous pleurodesis' occurs in a subset of patients (about $40 \%$ ) allowing secondary catheter removal [20]. Initial clinical assessment and follow-up by a respiratory physician are mandatory $[19,20]$. Catheters are inserted in the endoscopy suite or in an outpatient setting under local anesthesia similar to any classic small-bore chest tube. Symptom relief is achieved rapidly following its placement, and the relief of dyspnea is maintained along with eventual lung expansion by repeated drainage through the catheter in an outpatient setting. Drainage is performed every other day using disposable plastic bottles (0.5-1 liters), while patients with rapid fluid re-accumulation require daily procedures. Home care nursing support for catheter care and drainage is mandatory [20]. Patients and family members are also encouraged to learn the drainage procedure, facilitating additional drainage if necessary [20]. Although costs seem to be acceptable [21], they need to cover all treatments, interventions (including those at home) and materials related to the care of IPC-treated patients. In a recent study [22], repeat thoracocentesis was the cheapest intervention (USD 4,946) in the 3-month survival analysis while bedside pleurodesis was the cheapest in the 12-month analysis (USD 13,057). Unfortunately, to this day, there are no prospective long-term data directly comparing the costs of different methods; therefore, more research is needed in this area [20]. However, should we really compare IPC to pleurodesis?

In patients with malignant pleurisy, a study comparing IPCs to talc pleurodesis showed significantly shorter hospital stays, successful relief of dyspnea for IPCs and no difference in the complication rates [23]. However, it is important to notice that in this study the pleurodesis arm was inhomogeneous as patients treated with talc slurry and medical and surgical thoracoscopy poudrage were included. When adjusted for follow-up modalities, there was no significant improvement in duration of hospitalization or relief of dyspnea [23]. A more recent study randomizing IPCs to talc slurry showed an equal relief of dyspnea and quality of life with a shorter hospital stay, while overall complications rates were significantly higher (40 vs. 13\%) for the group treated with IPCs [24]. Furthermore, a newer technique, although preliminary, combining thoracoscopy poudrage with IPC suggests that pleurodesis is feasible and allows patients to be discharged the day after the procedure [25].

Complications are different from one method to another and therefore difficult to compare [20]. The most frequent IPC complications are dislocation of the catheter, local infections, repositioning of the catheter due to initial misplacement, pain and discomfort of the patient related to the long-term port access and catheter blockage leading to poor drainage and finally catheter removal [19]. These complications may be related to changes in IPC materials produced, which necessitate a close surveillance protocol [26]. Complications of pleurodesis are mainly subcutaneous emphysema, local infections, and pain during and after the procedure. A slight increase in body temperature due to local inflammatory reactions producing symphysis should not be considered as a complication [27]. Respiratory failure and acute respiratory distress syndrome (ARDS) as a result of talc does not concern Luzenac talc, and it is a huge mistake not to differentiate between different kinds of talc $[12,13]$. Indeed, a previous study in animals clearly showed no systemic dissemination or organ deposition of Luzenac talc particles [28]. These data were confirmed by a large clinical trial, which did not show a single case of ARDS [29]. Small-particle talc is associated with ARDS, respiratory insufficiency and poor outcome of pleurodesis [30], and, therefore, it should not be used any longer $[12,13]$. Mortality rates related to the procedure are extremely low for both IPCs $[19,20]$ and pleurodesis [14, 31]. In case of thoracoscopic talc pleurodesis, mortality is related to the patient's general 
health status and underlying respiratory condition [32] affecting respiratory muscle strength [33], while it is related to local complications in case of IPCs [20].

Also, techniques are different and therefore patient selection is different for pleurodesis or IPC. IPC introduction is a minimally invasive technique, which is performed in a sterile environment in patients with sufficient cytological confirmation with the simple goal of dyspnea relief. Thoracoscopy performed in the endoscopy suite is more invasive since it is also performed to obtain biopsies necessary for a histological diagnosis. When there is evidence of malignant lesions or when a rapid on-site diagnosis is available, the operator performs talc poudrage in the same setting after the evacuation of the fluid and adhesiolysis [34].

Thoracoscopic pleurodesis as first-line treatment is reserved for patients with a good health status and a long life expectancy, in whom a histological diagnosis is important together with anatomic and molecular staging of the disease, leading to changes in the treatment strategy [35-37]. IPCs should be utilized as second-line treatment after the failure of pleurodesis in MPE patients with adhesions or trapped lung, and in patients deemed unsuitable to undergo thoracoscopy due to a poor performance status and a short life expectancy, in the same way as bedside pleurodesis through a chest tube is indicated with different compounds. On the other hand, in case of non-MPE, IPC seems to be an interesting first-line treatment [38] either for elderly patients with end-stage disease or for young patients waiting for a heart, kidney or liver transplantation, in view of the fact that pleurodesis failed to achieve high efficacy in controlling dyspnea.

\section{Financial Disclosure and Conflicts of Interest}

The author has no conflicts of interest to disclose.

\section{References}

1 Froudarakis ME: Diagnostic work-up of pleural effusions. Respiration 2008;75:4-13.

2 Froudarakis M: Diagnostic thoracoscopy: malignant pleural effusion; in Astoul P, Tassi GF, Tschopp JM (eds): Thorcoscopy for Pulmonologists - A Didactic Approach. Berlin, Springer, 2014, pp 87-104.

- 3 Anevlavis S, Kouliatsis G, Sotiriou I, Koukourakis MI, Archontogeorgis K, Karpathiou G, Giatromanolaki A, Froudarakis ME: Prognostic factors in patients presenting with pleural effusion revealing malignancy. Respiration 2014;87:311-316.

-4 Rodriguez-Panadero F, Montes-Worboys A: Mechanisms of pleurodesis. Respiration 2012;83:91-98.

5 Bouros D, Froudarakis M, Siafakas NM: Pleurodesis: everything flows. Chest 2000; 118:577-579.

6 Viallat JR, Rey F, Astoul P, Boutin C: Thoracoscopic talc poudrage pleurodesis for malignant effusions. A review of 360 cases. Chest 1996;110:1387-1393.

-7 Colt HG, Russack V, Chiu Y, Konopka RG, Chiles PG, Pedersen CA, Kapelanski D: A comparison of thoracoscopic talc insufflation, slurry, and mechanical abrasion pleurodesis. Chest 1997;111:442-448.

8 Froudarakis ME: Pleural diseases in the molecular era - time for more answers: introduction. Respiration 2012;83:2-4.

-9 Agarwal R, Aggarwal AN, Gupta D, Jindal SK: Efficacy and safety of iodopovidone in chemical pleurodesis: a meta-analysis of observational studies. Respir Med 2006;100:2043-2047.
10 Walker-Renard PB, Vaughan LM, Sahn SA: Chemical pleurodesis for malignant pleural effusions. Ann Intern Med 1994;120:56-64.

-11 Lee YC, Lane KB, Parker RE, Ayo DS, Rogers JT, Diters RW, Thompson PJ, Light RW: Transforming growth factor beta(2) (TGF beta(2)) produces effective pleurodesis in sheep with no systemic complications. Tho$\operatorname{rax} 2000 ; 55: 1058-1062$.

12 Noppen M: Who's (still) afraid of talc? Eur Respir J 2007;29:619-621.

13 Aelony Y: Talc pleurodesis and acute respiratory distress syndrome. Lancet 2007;369: 1494-1496.

14 Rodriguez-Panadero F, Antony VB: Pleurodesis: state of the art. Eur Respir J 1997;10:16481654.

15 Harris K, Chalhoub M: The use of a PleurX catheter in the management of recurrent benign pleural effusion: a concise review. Heart Lung Circ 2012;21:661-665.

16 Cardenas A, Kelleher T, Chopra S: Review article: hepatic hydrothorax. Aliment Pharmacol Ther 2004;20:271-279.

$\checkmark 17$ Milanez de Campos JR, Filho LO, de Campos Werebe E, Sette H Jr, Fernandez A, Filomeno LT, Jatene FB: Thoracoscopy and talc poudrage in the management of hepatic hydrothorax. Chest 2000;118:13-17.

-18 Artemiou O, Marta GM, Klepetko W, Wolner E, Muller MR: Pleurovenous shunting in the treatment of nonmalignant pleural effusion. Ann Thorac Surg 2003;76:231-233.

-19 Bhatnagar R, Maskell NA: Indwelling pleural catheters. Respiration 2014;88:74-85.
20 MacEachern P, Tremblay A: Pleural controversy: pleurodesis versus indwelling pleural catheters for malignant effusions. Respirology 2011;16:747-754.

-21 Boshuizen RC, Onderwater S, Burgers SJ, van den Heuvel MM: The use of indwelling pleural catheters for the management of malignant pleural effusion - direct costs in a Dutch hospital. Respiration 2013;86:224-228.

-22 Puri V, Pyrdeck TL, Crabtree TD, Kreisel D, Krupnick AS, Colditz GA, Patterson GA, Meyers BF: Treatment of malignant pleural effusion: a cost-effectiveness analysis. Ann Thorac Surg 2012;94:374-380.

23 Fysh ET, Waterer GW, Kendall PA, Bremmer PR, Dina S, Geelhoed E, McCarney K, Morey S, Millward M, Musk AW, Lee YC: Indwelling pleural catheters reduce inpatient days over pleurodesis for malignant pleural effusion. Chest 2012;142:394-400.

-24 Davies HE, Mishra EK, Kahan BC, Wrightson JM, Stanton AE, Guhan A, Davies CW, Grayez J, Harrison R, Prasad A, Crosthwaite N, Lee YC, Davies RJ, Miller RF, Rahman NM: Effect of an indwelling pleural catheter vs chest tube and talc pleurodesis for relieving dyspnea in patients with malignant pleural effusion: the TIME2 randomized controlled trial. JAMA 2012;307:2383-2389.

25 Reddy C, Ernst A, Lamb C, Feller-Kopman D: Rapid pleurodesis for malignant pleural effusions: a pilot study. Chest 2010;139:14191423. 
26 Casal RF, Bashoura L, Ost D, Chiu HT, Faiz SA, Jimenez CA, Morice RC, Eapen GA: Detecting medical device complications: lessons from an indwelling pleural catheter clinic. Am J Med Qual 2013;28:69-75.

27 Froudarakis ME, Klimathianaki M, Pougounias M: Systemic inflammatory reaction after thoracoscopic talc poudrage. Chest 2006;129: 356-361.

28 Fraticelli A, Robaglia-Schlupp A, Riera H, Monjanel-Mouterde S, Cau P, Astoul P: Distribution of calibrated talc after intrapleural administration: an experimental study in rats. Chest 2002;122:1737-1741.

29 Janssen JP, Collier G, Astoul P, Tassi GF Noppen M, Rodriguez-Panadero F, Loddenkemper R, Herth FJ, Gasparini S, Marquette $\mathrm{CH}$, Becke B, Froudarakis ME, Driesen P, Bolliger CT, Tschopp JM: Safety of pleurodesis with talc poudrage in malignant pleural effusion: a prospective cohort study. Lancet 2007; 369:1535-1539.
30 Arellano-Orden E, Romero-Falcon A, Juan JM, Ocana Jurado M, Rodriguez-Panadero F, Montes-Worboys A: Small particle-size talc is associated with poor outcome and increased inflammation in thoracoscopic pleurodesis. Respiration 2013;86:201--209.

31 Boutin C, Loddenkemper R, Astoul P: Diagnostic and therapeutic thoracoscopy: techniques and indications in pulmonary medicine. Tuber Lung Dis 1993;74:225-239.

32 Lee P, Yap WS, Pek WY, Ng AW: An audit of medical thoracoscopy and talc poudrage for pneumothorax prevention in advanced COPD. Chest 2004;125:1315-1320.

3 Froudarakis ME, Pataka A, Makris D, Kouliatsis G, Anevlavis S, Sotiriou I, Steiropoulos P, Eleftheriadis S, Bouros D: Respiratory muscle strength and lung function in patients undergoing medical thoracoscopy. Respiration 2010;80:220-227.
34 Rodriguez-Panadero F: Medical thoracoscopy. Respiration 2008;76:363-372.

35 Astoul P, Roca E, Galateau-Salle F, Scherpereel A: Malignant pleural mesothelioma: from the bench to the bedside. Respiration 2012;83: 481-493.

36 Froudarakis ME: Pleural effusion in lung cancer: more questions than answers. Respiration 2012;83:367-376.

37 Schwarz C, Lubbert H, Rahn W, Schonfeld N, Serke M, Loddenkemper R: Medical thoracoscopy: hormone receptor content in pleural metastases due to breast cancer. Eur Respir J 2004;24:728-730.

38 Bhatnagar R, Reid ED, Corcoran JP, Bagenal JD, Pope S, Clive AO, Zahan-Evans N, Froeschle PO, West D, Rahman NM, Chatterji S, Sivasothy PR, Maskell NA: Indwelling pleural catheters for non-malignant effusions: a multicentre review of practice. Thorax 2013, Epub ahead of print. 